\title{
Recovery in stroke patients treated with fluoxetine versus placebo: A pooled analysis of 7,165 patients
}

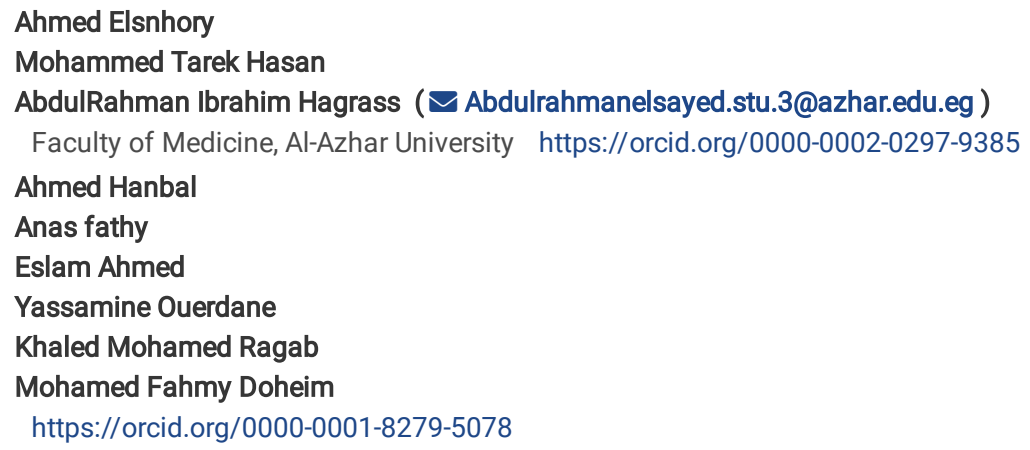

\section{Research Article}

Keywords: stroke, fluoxetine, placebo, recovery of function

Posted Date: December 29th, 2021

DOI: https://doi.org/10.21203/rs.3.rs-1175381/v1

License: () (7) This work is licensed under a Creative Commons Attribution 4.0 International License. Read Full License 


\section{Abstract \\ Purpose}

We conducted this study to build clear evidence regarding the outcomes of recovery in stroke patients treated with fluoxetine versus placebo.

\section{Methods}

Seventeen randomized clinical trials were identified by searching PubMed, Cochrane, Scopus, and Web of Science until June 2021.

\section{Results}

Fluoxetine enhances the National Institutes of Health Stroke Scale (NIHSS) score [MD $-0.67,95 \% \mathrm{Cl}(-1.19$ to -0.15$), \mathrm{P}=0.01]$ and the Fugl-Meyer Motor Scale (FMMS) score [MD 17.36, 95\% Cl (12.12 to 22.61), P < 0.00001] at three months follow up. However, the NIHSS score showed no significant difference between the two groups at two weeks [MD $-0.32,95 \% \mathrm{Cl}(-0.72$ to 0.07$), \mathrm{p}=0.11]$ or at six months [MD $-0.17,95 \% \mathrm{Cl}(-0.47$ to 0.14$), \mathrm{p}=0.29]$. Fluoxetine and placebotreated patients had the same overall impact on FMMS scores at one month [MD 7.77, $95 \% \mathrm{Cl}(-10.57$ to 26.11$), \mathrm{P}=0.41]$. The fluoxetine had a higher risk of broken bone $(\mathrm{RR}=2.30,95 \% \mathrm{Cl}[1.59,3.32], \mathrm{p}<0.001)$ and hyponatremia $(\mathrm{RR}=2.12,95 \% \mathrm{Cl}[1.19,3.76], \mathrm{p}=0.01)$ with lower risk of new depression $(\mathrm{RR}=0.72$, $95 \% \mathrm{Cl}[0.61,0.84], \mathrm{p}<0.001)$ in comparison to placebo.

\section{Conclusion}

The efficacy of fluoxetine on the NIHSS and FMMS is likely to take time to emerge and is expected to be transient. The BI score did not differ between the fluoxetine and placebo groups. The use of fluoxetine increased the incidence of hyponatremia and bone fractures while decreasing the risk of new-onset depression.

\section{Introduction}

Stroke is one of the predominant causes of permanent disability, mortality, significant cognitive, physical, and psychosocial morbidity in the world[1], [2]. It has three significant impacts on patients and their families: impairment, disability, and handicap. Furthermore, patients frequently experience depression following injury to either the right or left side of the brain[3]. The most prevalent and well-known disability induced by stroke is motor impairment[4]. At this time, stroke research has put its attention on therapeutic strategies that minimize neurological damage and improve stroke patients' functionality and recovery[5]. Regrettably, medication therapy designed to reduce the neurological damage had little effect[6]. Post-stroke depression and emotional impairment are treated with fluoxetine, an antidepressant, and selective serotonin reuptake inhibitor (SSRI)[7].

It is still unclear exactly how SSRIs impact rehabilitation from motor impairment[8]. SSRIs have been shown to enhance outcomes following a stroke in numerous clinical trials[9]-[11]. In 2011, the results of the FLAME trial showed that fluoxetine may enhance motor recovery and reduce dependence after three months through Modulation of spontaneous brain plasticity[12]. In animal stroke models, there was a significant benefit of therapy with SSRIs on neurobehavioral outcomes, but there was no detectable impact on infarct volume and there was no discernible influence affecting structural or functional outcomes as a result of the type of SSRI usage[13]. After 6 months of fluoxetine treatment, there is no improvement in the patients' modified Rankin Scale (mRS) as reported by the FOCUS trial[7]. Furthermore, the AFFINITY trial[14] reported that taking fluoxetine daily for six months didn't lead to better functional outcomes. They also observed an increased risk of bone fractures and epileptic episodes[7], [14]. In the EFFECTS trial, fluoxetine given orally showed limited benefit in functional outcomes, reduced the signs of depression, raised the chance of bone fractures, and caused hyponatremia[15]. To summarize, their research shows that fluoxetine should not be used in patients who have had an acute stroke[15]. Marquez-Romero et al,[8]suggested that adding fluoxetine to standard treatment early on was safe and helpful to speed up motor recovery 3 months following an intracerebral haemorrhage (ICH)[8].

Currently, the evidence regarding the effectiveness of SSRIs in improving specific cognitive domains, or dependency after stroke, is uncertain[16]. Also, if similar benefits in outcomes may be detected across populations are sustained following treatment cessation[16]. It was shown by Previous meta-analyses that fluoxetine could potentially improve the defective neurologic function if administered to stroke patients early after their accident[17]-[19]. But these studies used a limited number of patients and have low methodological quality in most included studies[17]-[19]. A meta-analysis by Liu et al,[20] detected an improvement in Fugl-Meyer Motor Scale (FMMS) and BI scores with no gain in mRS and National Institutes of Health Stroke Scale (NIHSS) scores which could be caused by the heterogeneity across the trials. Mead et al,[21] found that fluoxetine had no effect on disability or dependency following a stroke. This metaanalysis comprised just four high-quality studies with a significant degree of heterogeneity[21]. There is no subgroup analysis for treatment duration previous meta-analyses[20], [21], despite the fact that fluoxetine was used for three months in some trials and six months in others which could potentially influence the outcome. To elucidate the existing research gap and resolve the conflicting evidence regarding the safety and efficacy of fluoxetine for stroke patients, this comprehensive systematic review and meta-analysis (SR-MA) were conducted.

\section{Materials And Methods}

When performing this SR-MA, we followed the procedures outlined in the Cochrane Handbook for Systematic Reviews of Interventions[22]. This SR-MA was prepared in accordance with the PRISMA declaration requirements [23]. 
Literature search:

References were identified for this meta-analysis by searching PubMed, Cochrane Library, Scopus, and Web of Science for articles published from inception to June 2021, using the following MeSH terms "Stroke", "Fluoxetine", "MADRS", "NIHSS" and "Barthel-index". Only articles written in English were included.

Eligibility criteria:

We worked with Endnote X8 software (Thompson Reuter, CA, USA) to import collected records and to remove duplicate records. To verify the imported randomized controlled trials (RCTs), we screened the titles and abstracts and examined the full text of the relevant papers. We examined the references cited in those papers to find relevant articles. At least two authors worked independently to select studies and extract data. The difference of opinion was settled through discussion.

RCTs that met the following criteria were included: (I) Population: patients who are at least 18 years old and have stroke; (II) Intervention: Fluoxetine 20 mg daily given orally for 3-6 months; (III) Comparator: patients received placebo; (IV) Outcome parameters: efficacy outcomes including the mRS, NIHSS, FMMS, and the Barthel Index (BI); (V) study design: RCTs

The criteria for exclusion were as follows: (1) study type: observational studies, reviews, editorials, abstracts, thesis, letters, books, and chapters; (2) Studies whose data are not extractable or analysable.

Data extraction:

In the data extraction, all study authors participated equally. The following data items were extracted: 1) summary of the included studies: list of authors, site, study design, study arms, sample size, doses, length of follow up, outcomes, and results; 2) baseline characters of the included studies' population: age, sex, hypertension, dyslipidaemia, smoking, coronary artery disease, and diabetes mellitus; 3) efficacy outcomes: poststroke depression, excessive/ inappropriate crying, excessive/ inappropriate laughing, post-stroke anger proneness, Modified Rankin Scale, Montgomery-Asberg Depression Rating Scale (MADRS); 4) safety outcomes: insomnia, nausea, diarrhoea, recurrent stroke, acute coronary events, ischaemic stroke, other major bleeds, upper gastrointestinal bleed, haemorrhagic stroke, epileptic seizures, fall with injury, and death.

Risk of bias assessment:

It was assessed using the Cochrane Risk of Bias tool for each of the included studies[24]. Selection, performance, detection, attrition bias, reporting and other possible biases are assessed by this tool. Third-party reviewers assigned each bias domain a value of "low," "high" or "unclear".

Data synthesis:

For statistical analysis, we use Review Manager 5.4.1. All analyses used a fixed-effects model except if there is substantial heterogeneity in which we used the random-effects model. We calculated mean difference (MD) and 95 percent confidence interval (Cl) for continuous data and risk ratios (RRs) and $95 \% \mathrm{Cl}$ for dichotomous data in order to pool the data between the fluoxetine and control arms. A p-value of less than 0.05 was regarded as statistically significant. To determine heterogeneity, the chi-square and I-square tests were applied. When the chi-square P-value was less than 0.1 and the I-value was larger than $50 \%$, heterogeneity was considered.

\section{Results}

Results of the literature search:

A total of 1347 unique citations were identified during our search. 127 articles were selected for full-text screening. Subsequently, 17 randomized clinical trials[7], [8], [12], [14], [15], [25]-[36] including 7,165 participants (Fluoxetine arm participants were 3605 while placebo arm participants were 3560) were analysed in the quantitative portion of the study (Fig. 1).

\section{Characteristics of included studies:}

We were able to include 17 RCTs with 7365 participants in our analysis after we accepted all of the studies that fulfilled our inclusion criteria. We included all placebo-controlled studies assessing fluoxetine's efficacy and safety in poststroke patients. There were 16 studies[7], [8], [12], [14], [15], [25], [26], [28]-[36] which used a fluoxetine dosage of $20 \mathrm{mg}$ per day and only one study[27] began at $20 \mathrm{mg}$ daily and increased to a maximum of $40 \mathrm{mg}$ per day. Placebo is used as the control in all studies. Some studies used a third arm as citalopram[30], combining repetitive transcranial magnetic stimulation with fluoxetine[32], Shu-Gan-Jie-Yu[25], and an herbal drug[28]. Table 1 shows a summary of the design and principal outcomes of included studies, whereas Table 2 contains baseline characteristics of included studies participants.

\section{Risk of Bias Assessment Results:}

Based on the Cochrane risk of bias assessment tool, reviewed studies were of moderate to high quality. Fig. 2 summarises the quality assessment domains for all of the papers that were considered. In Table 5 Online Resource 1, the authors' opinions and explanations are both presented. The mean difference and $95 \% \mathrm{Cl}$ of efficacy outcomes are presented in Online Resource 1: Table 3.

Efficacy analysis: 


\section{NIHSS score:}

Fluoxetine was found to have a greater overall effect than placebo at three months [MD $-0.67,95 \% \mathrm{Cl}(-1.19$ to -0.15$), \mathrm{P}=0.01]$, the results were homogenous $\left(\mathrm{p}=0.40 ; \mathrm{I}^{2}=0 \%\right)$, but there was no difference between the two arms at two weeks [MD $-0.32,95 \% \mathrm{Cl}(-0.72$ to 0.07$\left.), \mathrm{p}=0.11\right]$, and six months [MD $-0.17,95 \% \mathrm{Cl}$ $(-0.47$ to 0.14$), p=0.29]$; pooled analysis were homogeneous at 2 weeks $\left(p=056 ; I^{2}=0 \%\right)$, and at 6 months $\left(p=0.06 ; I^{2}=65 \%\right)$ respectively $($ Fig. 3$)$.

\section{Barthel index (BI):}

The MD of change in $\mathrm{BI}$ showed no significance difference between the two arms at three months [MD $3.16,95 \% \mathrm{Cl}(-1.77$ to 8.08$)$; $\mathrm{P}=0.21]$ the results were homogenous $\left(p=0.86 ; I^{2}=0 \%\right)$, and the results were heterogeneous at six months [MD $1.26,95 \% \mathrm{Cl}(-4.79$ to 7.32$\left.) ; P=0.68\right]$ under a random effect model ( $p$ $\left.=0.03 ; 1^{2}=80 \%\right)$ (Fig. 4).

\section{FMMS scores:}

The overall effect showed no differences between the Fluoxetine group and placebo group at one month [MD 7.77, $95 \% \mathrm{Cl}(-10.57$ to 26.11$)$, P $=0.41]$. Pooled studies were heterogeneous under a random-effect model $\left(p=0.02 ; I^{2}=80 \%\right)$. However, the overall effect favoured the Fluoxetine group over placebo at three months [MD 17.36, $95 \% \mathrm{Cl}(12.12$ to 22.61), $\mathrm{P}<0.00001]$ and the results were homogenous $\left(\mathrm{p}=0.47 ; \mathrm{I}^{2}=0 \%\right)$, (Fig. 5).

\section{Stroke impact scale (SIS):}

The MD change of vitality favoured the placebo at six months [ $[\mathrm{MD}-2.01,95 \% \mathrm{Cl}(-3.37$ to -0.30$), \mathrm{P}=0.02]$, the results were homogeneous $\left(\mathrm{p}=0.89 ; \mathrm{I}^{2}=0 \%\right)$, and the other domains showed no significant difference between the two groups (Fig. 6).

\section{For all other efficacy outcomes:}

Overall, the Fluoxetine group did not outperform the placebo group except in Hamilton Depression Scale (HDS); The MD of change in HDS favoured the Fluoxetine group [MD $-2.60,95 \% \mathrm{Cl}(-5.19$ to -0.01$) ; \mathrm{P}=0.05]$ and the results were homogeneous $\left(\mathrm{p}=0.43 ; \mathrm{I}^{2}=0 \%\right)$, (Online Resource 1 : Fig. 7).

\section{Post-stroke depression:}

The overall effect shows no differences between the 2 groups at 3 - and 6-months ([MD $0.83,95 \% \mathrm{Cl}(0.46$ to 1.52$), \mathrm{P}=0.55]$, [MD $0.70,95 \% \mathrm{Cl}(0.36$ to 1.39$)$, $P=0.31$ respectively) and the results were homogenous $\left(p=0.11 ; 1^{2}=54 \%\right),\left(p=0.06 ; I^{2}=73 \%\right)$ at 3 and 6 months respectively, (Online Resource 1 : Fig. 8).

\section{Safety analysis:}

There were no significant differences in adverse events between the fluoxetine and placebo groups (Online Resource 1: Table 4) except hyponatremia and fractured bone; their frequency in fluoxetine group was significantly more than placebo group, $[(\mathrm{RR}=2.12,95 \% \mathrm{Cl}[1.19,3.76], \mathrm{p}=0.01),(\mathrm{RR}=2.30,95 \% \mathrm{Cl}[1.59$, 3.32], $p<0.001)$ ], the results were homogeneous $\left(p=0.18 ; l^{2}=41 \%\right)$ and $\left(p=0.62 ; l^{2}=41 \%\right)$ (Online Resource 1: Fig. 9 and Fig. 10, respectively)], but the frequency of new depression was significantly higher in the placebo group than fluoxetine group $(\mathrm{RR}=0.72,95 \% \mathrm{Cl}[0.61,0.84], \mathrm{p}<0.001)$, the pooled results were homogeneous $\left(p=0.76 ; I^{2}=0 \%\right)$ (Online Resource 1: Fig. 11).

\section{Discussion}

In this meta-analysis of usage of fluoxetine 20 mg for stroke patients, we identified 17 RCTs[7], [8], [12], [14], [15], [25]- [36] Which recruited 7165 (3605 in the treatment group and 3560 in the placebo group). For the efficacy outcome, we have used the changes of the obtained data to describe the degree of recovery. Fluoxetine was favoured on placebo in improving the NIHSS score and the FMMS score in the $3^{\text {rd }}$ month. The stroke impact scale (SIS) assessed the change in strength [MD $-1.63,95 \% \mathrm{Cl}(-4.27,1.01), \mathrm{P}=0.23]$ and vitality [MD $-2.01,95 \% \mathrm{Cl}(-3.37,-0.30), \mathrm{P}=0.02]$, and the placebo group showed superior improvement in these measurements at six months. Safety data showed that fluoxetine raised the risk of bone fracture and hyponatremia, but it was associated with lower chances of post-stroke depression. 
The NIHSS is commonly applied to provide an objective estimation of the severity of a stroke[37]. It calculates an overall score for each ability, ranging from 0 to 4 , A normal state is scored 0 , while a completely impaired state is scored 4 . The NIHSS score is the sum of all of the scale elements, and the maximum score is 42. A higher NIHSS score is associated with a greater level of impairment in stroke patients[37]. Our meta-analysis showed significant improvement in NIHSS score at 3 months but without any significance at 2 weeks or 6 months respectively, suggesting that fluoxetine effect needs time to occur and is considered as temporary from the pooled results of 6 RCTs.

As for the FMMS score which is an index designed for assessing the motor and joint function, balance, and sensation after stroke-induced hemiplegia[38], [39]. There were no significant differences between the Fluoxetine and placebo groups one month later. At three months, we exhibited a greater improvement, but the outcomes were heterogeneous. Patients and healthcare circumstances vary by trial, which could explain this disparity.

Disability or independence for daily tasks is evaluated by Bl, in which higher scores suggest better functioning[40]. Neither the fluoxetine nor the placebo groups showed significant differences at 3 or 6 months.

Fluoxetine showed better improvement in the Hamilton depression scale, which is the most used scale for detecting depression, Fluoxetine specificity resides in its effect in treating depression since it belongs to the SSRI family, and mostly used for its anti-depressive and emotional lability after stroke and also used for the treatment of the obsessive-compulsive disorder, and other mental disorders. The question that needs to be addressed is how fluoxetine affects the neurological scale and induces its post-stroke recovery effect. Some animal experiments have shown how fluoxetine could help with motor recovery[13]. The fact that SSRIs stimulate hippocampal and subventricular zone neurogenesis is quite intriguing[41]. Moreover, through the processes of neurogenesis, this could be a factor in a subsequent recovery following an episode of cerebral ischemia, with the possibility of new neurons migrating to the affected region[42], [43]. Fluoxetine enhances the secretion of the brain-derived neurotrophic factor, a neurotrophin strongly implicated in neuronal growth and survival and brain plasticity within Two suggested mechanisms: 5-HTT blockade and 5-HTT-independent direct activation of tropomyosin receptor kinase B (TrkB), which is the high-affinity receptor of the neurotrophin BDNF[44]. Furthermore, SSRIs can inhibit the inflammatory response the latter is the main cause of brain damage[18], [45], [46].

There is considerable brain damage area reduction and improved neurological function in mice treated with SSRIs 9 hours following the onset of stroke[47]. This reinforces the hypothesis that SSRIs have a beneficial effect on mice's neurological function. Other molecules are upregulated by SSRIs such as heme oxygenase-1 (HO-1) and hypoxia-inducible factor-1alpha which play a particular role in regulating cerebral blood flow[48]. Carbon monoxide is produced as a result of the HO-1 expression, which regulates vascular tone promoting better blood flow to the intended brain regions[49], and also SSRIs have been shown to increase the expression of $\beta-1$ adrenergic receptors in the brain of mice. [18]. Expression of these factors may improve functional recovery. Our results go hand in hand with animal studies conclusions and showed better amelioration in the function recovery predicted by the NIHSS score at 3 months, but the effect didn't last for too long and also by the improvement in FMMS score showed in the $3^{\text {rd }}$ month.

In terms of Safety outcomes, our analysis showed a higher risk for bone fracture and hyponatremia among the participants in the fluoxetine group. It is unknown how fluoxetine causes hyponatremia. According to a suggested mechanism, SIADH would be induced when there is an increase in the production of antidiuretic hormone (ADH) (serotonin has an effect on the 5-HT2 and 5-HT1C receptors) or an increased renal sensitivity to ADH[50], [51]. Another side effect of fluoxetine is the associated bone fracture. The long-term administration of an SSRI as a therapy for depression could lead to osteoporosis. The effects of SSRIs on osteoblasts[52], [53], osteocytes[54], osteoclasts[52], and various bone cell lines[55] have been examined in vitro.

The strengthening of our analysis resides in the included RCTs and their recruited number which is 7165 and it was bigger than the last published one[20] and a double of that of Mead et al[21]. The included RCTs were of high quality. We provide a subgroup analysis according to the duration of the follow-up to provide reliable results. A three-month treatment is not equivalent to a six-month treatment in terms of pharmacology, and the results may vary. This option was not provided in the previously published Meta-analysis. Our primary limitation is that we covered both types of strokes (ischemic and haemorrhagic). Knowing that different compositions of the participant groups may affect the results and induce slight heterogeneity which was observed in our analysis.

\section{Conclusion}

Short-term fluoxetine treatment failed to show any substantial improvement in the NIHSS and FMMS scores. There is a positive impact on NIHSS and FMMS scores at three months following therapy, however, at six months there is no significant change in NIHSS score. These findings demonstrate that fluoxetine's effect may take time to manifest and is assumed to be transient. There were no significant variations in BI score between the fluoxetine and placebo groups. Other than vitality, no significant differences were found in the SIS score between the fluoxetine and placebo groups. The only exception to this rule was for vitality, which favoured the placebo. The use of fluoxetine caused an increase in the risk of hyponatremia and bone fracture, but it lowered the possibility of developing a new-onset depression.

\section{Recommendations}

Much more research is required to pinpoint other therapies that may bring benefit and quantify such benefit in a clinical setting. Trials will have to be largesized, of high quality, and their target population must be well defined in order to reduce heterogeneity.

\section{Declarations}


Grant support: The authors have stated that they have received no financial assistance.

Conflicts of interest: The authors declare that they have no conflict of interest.

Patient consent for publication: The dissemination of this information does not require consent of patients.

\section{Authors' Contribution}

Conception and design of the work by Ahmed Elsnhory and Mohamed Fahmy Doheim.

Data collection by Mohammed Tarek Hasan, Ahmed Hanbal, Anas fathy, and Eslam Ahmed.

Data analysis and interpretation by Mohammed Tarek Hasan, Ahmed Hanbal, Anas fathy, and Eslam Ahmed.

Drafting the article by Yassamine Ouerdane, Ahmed Elsnhory, and Abdulrahman Ibrahim Hagrass.

Critical revision of the article by Abdulrahman Ibrahim Hagrass, Khaled Mohamed Ragab, and Mohamed Fahmy Doheim.

Final approval of the version to be published by Khaled Mohamed Ragab, and Mohamed Fahmy Doheim.

\section{References}

1. "Centers for Disease Control and Prevention. Underlying Cause of Death, 1999-2018. CDC WONDER Online Database. Atlanta, GA: Centers for Disease Control and Prevention (2018); Accessed March 12, 2020.\&\#8221

2. "Virani SS, Alonso A, Benjamin EJ, Bittencourt MS, Callaway CW, Carson AP et al (2020) Heart disease and stroke statistics-2020 update: a report from the American Heart Association. Circulation 141(9):e139-e596

3. “Folstein MF, Maiberger R, McHugh PR (1977)).”.Mood disorder as a specific complication of stroke. Journal of Neurology, Neurosurgery \& Psychiatry 40:1018-1020. doi:10.1136/jnnp.40.10.1018

4. “Wade DT (1992) Measurement in neurological rehabilitation. Curr Opin Neurol Neurosurg 5(5):682-686

5. “Powers WJ, Rabinstein AA, Ackerson T, Adevoe OM, Bambakidis NC, Becker K (2018) Guidelines for the Early Management of Patients With Acute Ischemic Stroke: A Guideline for Healthcare Professionals From the American Heart Association/American Stroke Association. J Vasc Surg. 2018;67(6):1934. doi: 10.1016/J.JVS.2018.04.007"

6. “De Keyser J, Sulter G, Luiten PG (1999))...Clinical trials with neuroprotective drugs in acute ischaemic stroke: are we doing the right thing? Trends Neurosci 22:535-540. doi:10.1016/S0166-2236(99)01463-0

7. “Dennis $\mathrm{M}$ et al (2019)).".Effects of fluoxetine on functional outcomes after acute stroke (FOCUS): a pragmatic, double-blind, randomised, controlled trial. The Lancet 393:265-274. doi:10.1016/S0140-6736(18)32823-X

8. “Marquez-Romero JM et al (2020)).".Fluoxetine for motor recovery after acute intracerebral hemorrhage, the FMRICH trial. Clin Neurol Neurosurg 190:105656-105656. doi: 10.1016/j.clineuro.2019.105656

9. DJ "JWW, JE D (2008) Chronic fluoxetine stimulates maturation and synaptic plasticity of adult-born hippocampal granule cells. J Neurosci 28(6):13741384.. doi:10.1523/JNEUROSCI.3632-07.2008”

10. SW “CML, JY K, C P, SH K (2009) Fluoxetine affords robust neuroprotection in the postischemic brain via its anti-inflammatory effect. J Neurosci Res 87(4):1037-1045.. doi:10.1002/JNR.21899"

11. "Siepmann T, Penzlin Al, Kepplinger J et al (2015) Selective serotonin reuptake inhibitors to improve outcome in acute ischemic stroke: possible mechanisms and clinical evidence. Brain Behav 5(10):e00373.. doi:10.1002/BRB3.373"

12. “Chollet F et al (2011)).".Fluoxetine for motor recovery after acute ischaemic stroke (FLAME): a randomised placebo-controlled trial. Lancet Neurol 10:123-130. doi:10.1016/S1474-4422(10)70314-8

13. “McCann SK et al (2014)).".Efficacy of Antidepressants in Animal Models of Ischemic Stroke. Stroke 45:3055-3063. doi:10.1161/STROKEAHA.114.006304

14. "Hankey GJ et al (2020)).".Safety and efficacy of fluoxetine on functional outcome after acute stroke (AFFINITY): a randomised, double-blind, placebocontrolled trial. Lancet Neurol 19:651-660. doi:10.1016/S1474-4422(20)30207-6

15. "Lundström E et al (2020)).".Safety and efficacy of fluoxetine on functional recovery after acute stroke (EFFECTS): a randomised, double-blind, placebocontrolled trial. Lancet Neurol 19:661-669. doi:10.1016/S1474-4422(20)30219-2

16. ZI "SHY (2017) Effects of Central Nervous System Drugs on Recovery After Stroke: A Systematic Review and Meta-Analysis of Randomized Controlled Trials. Clin Drug Investig 37(10):901-928.. doi:10.1007/S40261-017-0558-4"

17. "Yi ZM, Liu F, Zhai SD (2010 Aug) Fluoxetine for the prophylaxis of poststroke depression in patients with stroke: a meta-analysis. Int J Clin Pract 64(9):1310-1317. doi: 10.1111/j.1742-1241.2010.02437.x. PMID: 20653802."

18. “Mead GE et al (2012)).".Selective serotonin reuptake inhibitors (SSRIs) for stroke recovery. Cochrane Database of Systematic Reviews. doi: 10.1002/14651858.CD009286.pub2

19. "Gu SC, Wang CD (2018 May) Early Selective Serotonin Reuptake Inhibitors for Recovery after Stroke: A Meta-Analysis and Trial Sequential Analysis. J Stroke Cerebrovasc Dis 27(5):1178-1189. doi: 10.1016/j.jstrokecerebrovasdis.2017.11.031. Epub 2017 Dec 21. PMID: 29276014.”

Page $6 / 20$ 
20. "Liu G, Yang X, Xue T et al (2021) Is Fluoxetine Good for Subacute Stroke? A Meta-Analysis Evidenced From Randomized Controlled Trials. Front Neurol 12.. doi:10.3389/fneur.2021.633781"

21. “Mead GE, Legg L, Tilney R et al (2020) Fluoxetine for stroke recovery: Meta-analysis of randomized controlled trials. Int J Stroke 15(4):365-376.. doi:10.1177/1747493019879655"

22. Book Series “C, Higgins JP, Green SCochrane Handbook for Systematic Reviews of Interventions."

23. Moher "D, Liberati A, Tetzlaff J, Altman DG, Group TP (2009) Preferred Reporting Items for Systematic Reviews and Meta-Analyses: The PRISMA Statement. PLoS Medicine 6:e1000097.. doi: 10.1371/journal.pmed.1000097."

24. Green "ODA, Higgins S, Alderson PTJ, Clarke P, Mulrow M (2011) D C, Cochrane Handbook: Cochrane Reviews: Ch 8: Assessing risk of bias in included studies. In: Cochrane Handbook for: Systematic Reviews of Interventions. pp 3-10., 2011\&\#8221

25. "Gong L, Yang X, Feng Y et al (2020) The efficacy of integrative anti-depressive therapy on motor recovery after ischemic stroke - A randomized clinical trial. Eur J Integr Med 35(March):101102.. doi: 10.1016/j.eujim.2020.101102”

26. "He Y-T, Tang B-S, Cai Z-L, Zeng S-L, Jiang X, Guo Y (2016) Effects of Fluoxetine on Neural Functional Prognosis after Ischemic Stroke: A Randomized Controlled Study in China. J Stroke Cerebrovasc Dis 25(4):761-770.. doi: 10.1016/j.jstrokecerebrovasdis.2015.11.035"

27. “KONG Y (2007) Fluoxetine for poststroke depressionA randomized placebo controlled clinical trial. Neural Regen Res 2(3):162-165.. doi:10.1016/S16735374(07)60036-X"

28. "Li L-T, Wang S-H, Ge H-Y, Chen J, Yue S-W, Yu M (2008) The Beneficial Effects of the Herbal Medicine Free and Easy Wanderer Plus (FEWP) and Fluoxetine on Post-Stroke Depression. J Altern Complement Med 14(7):841-846.. doi:10.1089/acm.2008.0010"

29. "Wiart L, Petit H, Joseph PA, Mazaux JM, Barat M (2000) Fluoxetine in early poststroke depression: A double-blind placebo-controlled study. Stroke 31(8):1829-1832.. doi: 10.1161/01.STR.31.8.1829"

30. "Asadollahi M, Ramezani M, Khanmoradi Z, Karimialavijeh E (2018) The efficacy comparison of citalopram, fluoxetine, and placebo on motor recovery after ischemic stroke: a double-blind placebo-controlled randomized controlled trial. Clin Rehabil 32(8):1069-1075.. doi:10.1177/0269215518777791"

31. "Bembenek JP, Niewada M, Klysz B et al (2020) Fluoxetine for stroke recovery improvement - The doubleblind, randomised placebo-controlled FOCUSPoland trial. Neurol Neurochir Pol 54(6):544-551.. doi:10.5603/PJNNS.A2020.0099"

32. "Bonin Pinto C, Morales-Quezada L, de Toledo Piza PV et al (2019) Combining Fluoxetine and rTMS in Poststroke Motor Recovery: A Placebo-Controlled Double-Blind Randomized Phase 2 Clinical Trial. Neurorehabil Neural Repair 33(8):643-655.. doi:10.1177/1545968319860483"

33. "Choi-Kwon S, Han SW, Kwon SU, Kang DW, Choi JM, Kim JS (2006) Fluoxetine treatment in poststroke depression, emotional incontinence, and anger proneness a double-blind, placebo-controlled study. Stroke 37(1):156-161.. doi: 10.1161/01.STR.0000190892.93663.e2"

34. "Choi-Kwon S, Choi J, Kwon SU, Kang D-W, Kim JS (2007) Fluoxetine Is Not Effective in the Treatment of Poststroke Fatigue: A Double-Blind, PlaceboControlled Study. Cerebrovasc Dis 23(2-3):103-108.. doi:10.1159/000097045"

35. “Dam M, Tonin P, De Boni A et al (1996) Effects of Fluoxetine and Maprotiline on Functional Recovery in Poststroke Hemiplegic Patients Undergoing Rehabilitation Therapy. Stroke 27(7):1211-1214.. doi: 10.1161/01.STR.27.7.1211"

36. "Fruehwald S, Gatterbauer E, Rehak P, Baumhackl U (2003) Early fluoxetine treatment of post-stroke depression. J Neurol 250(3):347-351.. doi:10.1007/s00415-003-1014-3"

37. "Brott T, Adams HP, Olinger CP et al (1989) Measurements of acute cerebral infarction: a clinical examination scale. Stroke 20(7):864-870.. doi: 10.1161/01.STR.20.7.864"

38. “Fugl-Meyer AR, Jääskö L, Leyman I, Olsson S, Steglind S (1975) The post-stroke hemiplegic patient. 1. a method for evaluation of physical performance. Scand J Rehabil Med 7(1):13-31. http://www.ncbi.nlm.nih.gov/pubmed/1135616"

39. “Gladstone DJ, Danells CJ, Black SE (2002) The Fugl-Meyer Assessment of Motor Recovery after Stroke: A Critical Review of Its Measurement Properties. Neurorehabil Neural Repair 16(3):232-240.. doi:10.1177/154596802401105171"

40. "Uyttenboogaart M, Stewart RE, Vroomen PCAJ, De Keyser J, Luijckx G-J (2005) Optimizing Cutoff Scores for the Barthel Index and the Modified Rankin Scale for Defining Outcome in Acute Stroke Trials. Stroke 36(9):1984-1987.. doi: 10.1161/01.STR.0000177872.87960.61"

41. "Taupin P (2006) Adult neurogenesis and neuroplasticity. Restor Neurol Neurosci 24(1):9-15. http://www.ncbi.nlm.nih.gov/pubmed/16518023"

42. LANG “WILTROUTC, YAN B, DEMPSEY Y, VEMUGANTI R (2007) Repairing brain after stroke: A review on post-ischemic neurogenesis. Neurochem Int 50(7-8):1028-1041.. doi: 10.1016/j.neuint.2007.04.011"

43. “Dempsey RJ, Sailor KA, Bowen KK, Türeyen K, Vemuganti R (2003) Stroke-induced progenitor cell proliferation in adult spontaneously hypertensive rat brain: effect of exogenous IGF-1 and GDNF. J Neurochem 87(3):586-597.. doi:10.1046/j.1471-4159.2003.02022.x"

44. "Levy MJF, Boulle F, Emerit MB et al (2019) 5-HTT independent effects of fluoxetine on neuroplasticity. Sci Rep 9(1):6311.. doi:10.1038/s41598-01942775-w"

45. "Dirnagl U, ladecola C, Moskowitz MA (1999) Pathobiology of ischaemic stroke: an integrated view. Trends Neurosci 22(9):391-397.. doi:10.1016/S01662236(99)01401-0"

46. "Kirino T (2000) Delayed neuronal death. Neuropathology 20(s1):95-97.. doi:10.1046/j.1440-1789.2000.00306.x"

47. "Lim C-M, Kim S-W, Park J-Y, Kim C, Yoon SH, Lee J-K (2009) Fluoxetine affords robust neuroprotection in the postischemic brain via its anti-inflammatory effect. J Neurosci Res 87(4):1037-1045.. doi:10.1002/jnr.21899”

48. “Ozaki H, Yu AY, Della N et al (1999) Hypoxia inducible factor-1alpha is increased in ischemic retina: temporal and spatial correlation with VEGF expression. Invest Ophthalmol Vis Sci 40(1):182-189. ”.

Page $7 / 20$ 
49. "Shin TK, Kang MS, Lee HY et al (2009) Fluoxetine and Sertraline Attenuate Postischemic Brain Injury in Mice. Korean J Physiol Pharmacol 13(3):257.. doi:10.4196/kjpp.2009.13.3.257"

50. “Lappin RI, Auchincloss EL (1994) Treatment of the Serotonin Syndrome with Cyproheptadine. N Engl J Med 331(15):1021-1022.. doi:10.1056/NEJM199410133311514"

51. "Graudins A, Stearman A, Chan B (1998) Treatment of the serotonin syndrome with cyproheptadine. J Emerg Med 16(4):615-619.. doi:10.1016/S07364679(98)00057-2"

52. “Hodge JM, Wang Y, Berk M et al (2013) Selective Serotonin Reuptake Inhibitors Inhibit Human Osteoclast and Osteoblast Formation and Function. Biol Psychiatry 74(1):32-39.. doi: 10.1016/j.biopsych.2012.11.003"

53. “Cray JJ, Weinberg SM, Parsons TE, Howie RN, Elsalanty M, Yu JC (2014) Selective serotonin reuptake inhibitor exposure alters osteoblast gene expression and craniofacial development in mice. Birth Defects Res Part A Clin Mol Teratol 100(12):912-923.. doi:10.1002/bdra.23323"

54. "Bliziotes MM, Eshleman AJ, Zhang X-W, Wiren KM (2001) Neurotransmitter action in osteoblasts: expression of a functional system for serotonin receptor activation and reuptake. Bone 29(5):477-486.. doi:10.1016/S8756-3282(01)00593-2"

55. "Salai M, Somjen D, Gigi R, Yakobson O, Katzburg S, Dolkart O (2013) Effects of commonly used medications on bone tissue mineralisation in SaOS-2 human bone cell line. Bone Joint J 95-B(11):1575-1580.. doi:10.1302/0301-620X.95B11.31158"

\section{Tables}

Table 1: A summary of the design and main results of included studies 


\begin{tabular}{|c|c|c|c|c|c|c|c|c|c|}
\hline Study ID & Site & $\begin{array}{c}\text { Study } \\
\text { design }\end{array}$ & $\begin{array}{c}\text { Study } \\
\text { arms, } \\
\text { samples, } \\
\text { and doses }\end{array}$ & $\begin{array}{l}\text { length of } \\
\text { follow up } \\
\text { (weeks) }\end{array}$ & protocol registration & $\begin{array}{c}\text { Primary } \\
\text { outcomes }\end{array}$ & $\begin{array}{l}\text { secondary } \\
\text { outcomes }\end{array}$ & Conclusion & $\overline{\text { resul } 1}$ \\
\hline $\begin{array}{c}\text { Asadollahi } \\
2018\end{array}$ & $\begin{array}{c}\text { university- } \\
\text { affiliated } \\
\text { teaching hospital } \\
\text { in Tehran, Iran }\end{array}$ & $\begin{array}{l}\text { RCTs } 3 \\
\text { arms }\end{array}$ & $\begin{array}{c}3 \text { arms } \\
\text { (fluoxetine } \\
20 \mathrm{mg} \\
\mathrm{N}=30 \& \\
\text { placebo } \\
\mathrm{N}=30 \& \& \\
\text { citalopram } \\
20 \mathrm{mg} \\
\mathrm{N}=30 \text { ) }\end{array}$ & 13.036 & IRCT20141116019971N3 & $\begin{array}{c}\text { Functional } \\
\text { status at } 90 \\
\text { days by the } \\
\text { Fugl-Meyer } \\
\text { Motor Scale } \\
\text { score. }\end{array}$ & & $\begin{array}{c}\text { Citalopram } \\
\text { and fluoxetine } \\
\text { were similarly } \\
\text { effective in } \\
\text { motor } \\
\text { recovery for } \\
\text { ischemic } \\
\text { stroke } \\
\text { patients. In } \\
\text { contrast to a } \\
\text { placebo, both } \\
\text { medications } \\
\text { were found to } \\
\text { be effective in } \\
\text { improving } \\
\text { motor function } \\
\text { after a stroke. }\end{array}$ & $\begin{array}{r}\text { In compal } \\
\text { to the bas } \\
\text { FMMS sc } \\
\text { the me } \\
\text { FMMS sc } \\
\text { reveale } \\
\text { significe } \\
\text { increase } \\
\text { the fluoxe } \\
\text { and citalo } \\
\text { group } \\
(\mathrm{P}=0.00\end{array}$ \\
\hline $\begin{array}{c}\text { Bembenek } \\
2020\end{array}$ & $\begin{array}{l}\text { Institute of } \\
\text { Psychiatry and } \\
\text { Neurology in } \\
\text { Warsaw }\end{array}$ & $\begin{array}{l}\text { RCTs } \\
\text { double } \\
\text { armed }\end{array}$ & $\begin{array}{c}2 \text { arms } \\
\text { (fluoxetine } \\
20 \mathrm{mg} \\
\mathrm{N}=30 \& \\
\text { placebo } \\
\mathrm{N}=31 \text { ) }\end{array}$ & $\begin{array}{c}2 \text { measures } \\
\text { period }(6 \\
\text { month }=26.7 \\
\text { weeks } \& 12 \\
\text { month }=52.14)\end{array}$ & $\begin{array}{c}\text { Pol 2020; } 54(6): 544- \\
551)\end{array}$ & $\begin{array}{c}\text { Disability on } \\
\text { mRS at six } \\
\text { months. }\end{array}$ & $\begin{array}{l}\text { BI \&NIHH after } \\
6 \text { and } 12 \text { months }\end{array}$ & $\begin{array}{l}\text { At six and } \\
\text { twelve } \\
\text { months, } \\
\text { fluoxetine did } \\
\text { not affect } \\
\text { motor } \\
\text { recovery or } \\
\text { overall stroke } \\
\text { prognosis. } \\
\text { Fluoxetine } \\
\text { treated } \\
\text { patients } \\
\text { required fewer } \\
\text { antidepressant } \\
\text { drugs. }\end{array}$ & $\begin{array}{r}\text { Fluoxeti } \\
\text { treate } \\
\text { patients } ~ \\
\text { less likel } \\
\text { be prescr } \\
\text { a neu } \\
\text { antidepres } \\
\text { than the } \\
\text { who rece } \\
\text { the placı } \\
\text { throughol } \\
\text { months } \\
\text { [6.67\%] } \\
{[12.90 \%}\end{array}$ \\
\hline boninpinto2019 & $\begin{array}{c}\text { Spaulding } \\
\text { Neuromodulation } \\
\text { Center, Boston, } \\
\text { Massachusetts }\end{array}$ & $\begin{array}{l}\text { RCTs } 3 \\
\text { arms }\end{array}$ & $\begin{array}{c}3 \text { arms } \\
\text { (Combined } \\
\text { (Fluoxetine } \\
+ \text { rTMS) (n } \\
=9) \text { ) \& } \\
\text { (Fluoxetine } \\
\text { 20mg ( }= \\
10) \\
\text { Placebo (n } \\
=8) \text { ) }\end{array}$ & 12.86 & NCT02208466 & $\begin{array}{l}\text { motor function } \\
\text { scales: JTHF } \\
\text { and FMA upper } \\
\text { extremity } \\
\text { changes from } \\
\text { day } 0 \text { to day } 90\end{array}$ & $\begin{array}{c}\text { MAS, BDI, } \\
\text { MMSE, diary of } \\
\text { drugs, adverse } \\
\text { reactions of } \\
\text { antidepressants, } \\
\text { and } \\
\text { assessments on } \\
\text { rTMS adverse } \\
\text { reactions. }\end{array}$ & $\begin{array}{c}\text { Fluoxetine } \\
\text { administration } \\
\text { along with } \\
\text { rTMS has } \\
\text { been shown to } \\
\text { improve } \\
\text { stroke-related } \\
\text { motor } \\
\text { functions } \\
\text { better than } \\
\text { fluoxetine } \\
\text { administration } \\
\text { alone and } \\
\text { placebo. } \\
\text { Fluoxetine's } \\
\text { effects on } \\
\text { intracortical } \\
\text { facilitation } \\
\text { show a } \\
\text { possible } \\
\text { diffuse } \\
\text { mechanism } \\
\text { that could } \\
\text { inhibit motor } \\
\text { recovery } \\
\text { gains. }\end{array}$ & $\begin{array}{r}\text { Comparis } \\
\text { fluoxetine } \\
\text { placeb } \\
\text { showed } 1 \\
\text { fluoxetin€ } \\
\text { have } \\
\text { negati } \\
\text { impact on } \\
\text { scales } \\
\text { (respecti } \\
\text { JTHF: }-5 \\
\text { vs -117 } \\
\text { seconds, } \\
0.038 ; \text { a } \\
\text { FMA: } 6.7 \\
\text { 15.55 poir } \\
=0.03 \subseteq \\
\text { suggest } \\
\text { that fluox } \\
\text { may have } \\
\text { negati } \\
\text { conseque } \\
\text { on the us } \\
\text { health. Ir. } \\
\text { combined } \\
\text { fluoxeti } \\
\text { groups, } \\
\text { unaffect } \\
\text { hemisph } \\
\text { exhibite } \\
\text { significe } \\
\text { decreası } \\
\text { intracort } \\
\text { inhibiti } \\
\text { while t] } \\
\text { fluoxeti } \\
\text { intracor shc } \\
\text { facilitati }\end{array}$ \\
\hline $\mathrm{cl}$ & $\begin{array}{l}\text { Asan Medical } \\
\text { Center }\end{array}$ & $\begin{array}{l}\text { RCTs } \\
\text { double } \\
\text { armed }\end{array}$ & $\begin{array}{c}2 \text { arms } \\
\text { (fluoxetine } \\
20 \mathrm{mg} \\
\mathrm{N}=67 \&\end{array}$ & 26.07 & 2006;37:156-161 & $\begin{array}{l}\text { The scores of } \\
\text { emotional } \\
\text { disturbances at }\end{array}$ & $\begin{array}{l}\% \text { improvements } \\
\text { in BDI scores, \% } \\
\text { improvements in } \\
\text { VAS scores and }\end{array}$ & $\begin{array}{l}\text { Fluoxetine is } \\
\text { successful in } \\
\text { curing PSEI } \\
\text { and PSAP. It is }\end{array}$ & $\begin{array}{r}\text { Despite } \\
\text { fact th } \\
\text { individua } \\
\text { the fluoxe }\end{array}$ \\
\hline
\end{tabular}

Page 9/20 
placebo

$\mathrm{N}=76$ ) each follow-up assessment

choi-kwon2006 $\quad$ clinics at the
Asan Medical
Center

$\begin{array}{cc}\text { RCTs } & 2 \text { arms } \\ \text { double } & \text { (fluoxetine } \\ \text { armed } & 20 \mathrm{mg} \\ & \mathrm{N}=40 \& \\ & \text { placebo } \\ & \mathrm{N}=43 \text { ) }\end{array}$

26.07

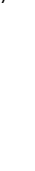

\section{PSAP scores; In contrast to the patient's}

original replies before

enrolment, the patients

subjective

responses are reported as

"aggravated,"

"no change,"

and "improved". chollet2011 enrolled from nine stroke units

in France
RCTs
2 arms; 20
$\mathrm{mg}$
armed fluoxetine
qd ( $\mathrm{n}=59)$
$\&$ placebo
$(\mathrm{n}=59)$

$\begin{array}{cc}\text { Mean VAS } & \text { The \% changes } \\ \text { score for PoSF } & \text { in VAS and FSS } \\ \text { and the mean } & \text { scores, } \\ \text { FSS score } & \begin{array}{c}\text { compared to } \\ \text { their original } \\ \text { scores. }\end{array}\end{array}$

change in

FMMS score.

NCT00657163.

currently

unknown

whether or not

PSD is

significantly

impacted by it.

to
While some

associated

mental

disturbances

improved

dramatically,

fluoxetine

does not

improve PoSF

Our findings

indicate that

PoSF might be

related to a

variety of

etiologies, but

does not

appear to be

closely tied to

serotonin-

related

dysfunction.

The use of

fluoxetine and

rehabilitation

services in

patient

populations

with ischemic

stroke and

motor

impairments

improves

motor

recovery after

three months.

the promising

treatmen

avenue for

patients with

ischemic

stroke and

motor

impairments is

modulation

spontaneous

brain

plasticity.

One possible Improver

interpretation

is that

fluoxetine

might help or,

alternatively,

maprotiline

may delay grour withdre

more

frequently

to side eff

fluoxeti

medicat

was relat

safe. PSE

PSAP W

greatl

enhancer

fluoxeti:

however

apprecia

improven

of PSD i

detecte

PSAP w

enhanced

after $3 \mathrm{mc}$

after tl

medicat

was ceas

The init

mean fat:

VAS score

the me

overall $\mathrm{F}$

core wer

2.0 anc

$\& 1.2$

respectir

Howevt

PoSF patj

who rece

fluoxetine

more

improven

in emotic

incontine

( $\mathrm{p}=0.05)$

depress

$(\mathrm{p}=0.05)$

those in

placebo :

Hyponatre

tempori

digesti

disorde

includis

nause:

diarrhea,

abdomis

discomf

hepati

enzym

problen

psychiat

disorde

sleepless

and par

seizure $n$

the prim

side eve

seen in

fluoxetine placeb groups 
dennis 2018

at 103 hospitals

in the UK

$\begin{array}{cccc}\text { RCTs } & 2 \text { arms } & 26.07 & \text { ISRCTN83290762 } \\ \text { double } & \text { (fluoxetine } & \\ \text { armed } & 20 \mathrm{mg} & \\ & \mathrm{N}=1564 & \\ & \& \text { placebo } & \\ & \mathrm{N}=1563) & \end{array}$

daily living

(ADL)

functional
status,
measured with
the mRS, at the
6-month follow-

up.

$$
\begin{gathered}
\text { poststroke } \\
\text { patients' } \\
\text { recovery in a } \\
\text { rehabilitation } \\
\text { setting. Since } \\
\text { combining } \\
\text { fluoxetine with } \\
\text { physical } \\
\text { therapy may } \\
\text { lead to better } \\
\text { functional } \\
\text { outcomes } \\
\text { after a stroke, } \\
\text { further } \\
\text { evaluation of } \\
\text { this treatment } \\
\text { should be } \\
\text { done. }
\end{gathered}
$$

all arms. s participe

who rece

fluoxeti

experien

an

improven

of $36 \%$ in

HSS Gí

mean scc

$16 \%$

improven

in the

maprotil

arm, and

improven

in the pla

arm. the

mean va]

Shaw c

improven

of $61 \%$, 3

and $55^{\prime}$

respectiv

Survival at six It does not

appear that

the

Fluoxetint

placeb

treate

patients $\mathrm{r}$

similar de

of disper

across $\mathrm{n}$

categories

month

(common

ratio adju for

minimiza

variabl

0.951 [95

0.839-1•(

$\mathrm{p}=0.43$

patients

were gir

fluoxeti

were le

likely to 1

new case

depress

emerge a

six mon

(210 [13•

patients

269 [17.2

differer.

3.78\% [95

$1 \cdot 26-6 \cdot$ :

$\mathrm{p}=0 \cdot 00$ ?

But mo

broken bc

were pre

(45 [2•88

$23[1 \cdot 47$

differer.

$1.41 \%$ [95

$0 \cdot 38-2 \cdot 4$

$\mathrm{p}=0 \cdot 007$

There we] signifić

changes i:

results of

other eve

both 6-m

and 12-m

timefran

In the

HDS average

fluctuations at

three months

and long-term

follow-up, the

interventions

may have

treatment

SSS, BDI, and contributed to

spontaneous

recovery from fluoxeti group, $\mathrm{E}$ values $f$ over time elevated c 


\begin{tabular}{|c|c|c|c|c|c|c|c|c|c|}
\hline \multirow{2}{*}{ gong2020 } & \multirow[b]{2}{*}{$\begin{array}{c}\text { Shuguang } \\
\text { Hospital and } \\
\text { Pudong Hospital }\end{array}$} & \multirow[b]{2}{*}{$\begin{array}{l}\text { RCTs } 4 \\
\text { arms }\end{array}$} & \multirow[b]{2}{*}{$\begin{array}{c}4 \text { arms: } \\
\text { Group A } \\
\text { (Shu-Gan- } \\
\text { Jie-Yu only, } \\
720 \text { mg/ } \\
\text { once PO, } \\
\text { three times } \\
\text { per day), } \\
\text { Group B } \\
\text { (fluoxetine } \\
\text { 20mg PO } \\
\text { daily ), } \\
\text { Group C } \\
\text { (Shu-Gan- } \\
\text { Jie-Yu and } \\
\text { fluoxetine), } \\
\text { and Group } \\
\text { D } \\
\text { (placebo) }\end{array}$} & \multirow[b]{2}{*}{12.86} & \multirow[b]{2}{*}{ SHZYY-SGYY211605-18 } & \multirow[b]{2}{*}{$\begin{array}{c}\text { FMMS score, } \\
\text { cerebral- } \\
\text { infarction site, } \\
\text { NIHSS score, } \\
\text { FMMS score, } \\
\text { and modified } \\
\text { Rankin Scale } \\
\text { (mRS) score }\end{array}$} & & \\
\hline & & & & & & & & $\begin{array}{l}\text { Shu-Gan-Jie-Yu } \\
\text { (a traditional } \\
\text { Chinese } \\
\text { medicine) } \\
\text { gave equal } \\
\text { gains in motor } \\
\text { recovery after } \\
\text { ischemic } \\
\text { stroke to } \\
\text { Western } \\
\text { medicine } \\
\text { (fluoxetine). }\end{array}$ & $\begin{array}{r}\text { enhanc } \\
\text { motor abi } \\
(\mathrm{P}<0.05 \\
\text { the thr } \\
\text { groups) } \mathrm{V} \\
\text { the numb } \\
\text { cases wit } \\
\text { mRS scol } \\
0-1 \text { increc } \\
\text { so did t } \\
\text { percentag } \\
\text { all } 3 \text { grou] } \\
<0.01) \\
\text { contrast } \\
\text { placeb }\end{array}$ \\
\hline hankey 2020 & $\begin{array}{c}\text { A total of } 43 \\
\text { units located in } \\
\text { Australia }(n=29) \text {, } \\
\text { New Zealand } \\
(n=4) \text {, and } \\
\text { Vietnam }(n=10) .\end{array}$ & $\begin{array}{l}\text { RCTs } \\
\text { double } \\
\text { armed }\end{array}$ & $\begin{array}{c}2 \text { arms } \\
\text { (fluoxetine } \\
20 \mathrm{mg} \\
\mathrm{N}=642 \& \\
\text { placebo } \\
\mathrm{N}=638 \text { ) }\end{array}$ & 26.07 & ACTRN12611000774921 & $\begin{array}{c}\text { mRS at } 6 \\
\text { months after } \\
\text { randomization }\end{array}$ & $\begin{array}{c}\text { Depression, } \\
\text { cognitive ability, } \\
\text { communication, } \\
\text { motor control, } \\
\text { HRQoL, overall } \\
\text { health status, } \\
\text { adherence to } \\
\text { the intervention, } \\
\text { and a new } \\
\text { diagnosis of } \\
\text { depression to be } \\
\text { treated with } \\
\text { antidepressants, } \\
\text { were studied. }\end{array}$ & $\begin{array}{l}\text { Following a } \\
\text { stroke, an } \\
\text { additional } 6 \\
\text { months of oral } \\
\text { fluoxetine } \\
\text { treatment did } \\
\text { not result in } \\
\text { any functional } \\
\text { benefits and } \\
\text { was } \\
\text { associated } \\
\text { with a higher } \\
\text { risk of } \\
\text { fractures, } \\
\text { falls, and } \\
\text { seizures. The } \\
\text { findings don't } \\
\text { encourage } \\
\text { using } \\
\text { fluoxetine to } \\
\text { help stroke } \\
\text { patients. }\end{array}$ & $\begin{array}{r}\text { In th€ } \\
\text { fluoxeti } \\
\text { group } \\
\text { patien } \\
\text { experien } \\
\text { significa } \\
\text { more falls } \\
\text { [3\%] vs sı } \\
{[1 \%] ;} \\
p=0.01 ; \\
\text { broken b } \\
\text { (19 [3\%] } \\
{[1 \%]} \\
\text { p=0.014), } \\
\text { convulsi } \\
\text { (ten }[2 \% \\
\text { two }[<1 \\
\mathrm{p}=0.038) \\
\text { month }\end{array}$ \\
\hline he 2016 & China & $\begin{array}{l}\text { RCTs } \\
\text { double } \\
\text { armed }\end{array}$ & $\begin{array}{c}2 \text { arms } \\
\text { (fluoxetine } \\
20 \mathrm{mg} \\
\mathrm{N}=642 \& \text { \& } \\
\text { placebo } \\
\mathrm{N}=638 \text { ) }\end{array}$ & 25.7 & ChiCTR-TRC-12002078. & $\begin{array}{c}\text { The NIHSS } \\
\text { scores on days } \\
15,90 \text {, and } 180 \\
\text { after } \\
\text { enrollment }\end{array}$ & $\begin{array}{l}\text { The BI scores at } \\
\text { days } 90 \text { and } 180 \\
\text { after enrollment }\end{array}$ & $\begin{array}{l}\text { In treating } \\
\text { patients } \\
\text { following an } \\
\text { ischemic } \\
\text { stroke with } \\
\text { fluoxetine for } \\
90 \text { days, } \\
\text { patients can } \\
\text { have long-term } \\
\text { improvements } \\
\text { in their brain } \\
\text { functional } \\
\text { results. }\end{array}$ & $\begin{array}{r}\text { The me } \\
\text { post-treat } \\
\text { NIHSS sı } \\
\text { in the } \\
\text { treatm } \\
\text { group } \mathrm{x} \\
\text { consideri } \\
\text { lower tha: } \\
\text { control g] } \\
\text { (P =.00 } \\
\text { There wi } \\
\text { statistici } \\
\text { significe } \\
\text { differenc } \\
\text { the mear } \\
\text { scores on } \\
90 \text { and } 1 \\
\text { between } \\
\text { treatment } \\
\text { (P = .026) } \\
\text { the cont } \\
\text { arm (P } \\
.011) . \text { In } \\
\text { treatm } € \\
\text { group, } \\
\text { benefi }\end{array}$ \\
\hline
\end{tabular}




\begin{tabular}{|c|c|c|c|c|c|}
\hline kong2007 & $\begin{array}{l}\text { First Hospital } \\
\text { Affiliated to } \\
\text { Soochow } \\
\text { University }\end{array}$ & $\begin{array}{c}\text { RCTs } \\
\text { double } \\
\text { armed }\end{array}$ & $\begin{array}{c}2 \text { arms } \\
\text { (fluoxetine } \\
20 \mathrm{mg} \\
\mathrm{N}=642 \& \\
\text { placebo } \\
\mathrm{N}=638 \text { ) }\end{array}$ & 8 & $\begin{array}{c}\text { HAMD, ADL, } \\
\text { and } \\
\text { neurological } \\
\text { impairment, } \\
\text { and plasma and } \\
\text { platelet 5-HT } \\
\text { concentrations } \\
\text { after two, four, } \\
\text { and eight } \\
\text { weeks. }\end{array}$ \\
\hline
\end{tabular}

\begin{tabular}{|c|c|c|c|c|c|}
\hline li2008 & $\begin{array}{c}\text { in Qilu Hospital } \\
\text { of Shandong } \\
\text { University }\end{array}$ & $\begin{array}{l}\text { RCTs } 3 \\
\text { arms }\end{array}$ & $\begin{array}{c}3 \text { arms: } \\
\text { FEWP } \\
\text { group, } 18 \mathrm{~g} \\
\text { twice daily } \\
(\mathrm{N}=60) \\
\& \\
\text { fluoxetine, } \\
18 \mathrm{~g} \text { twice } \\
\text { daily group } \\
(\mathrm{N}=60) \& \\
\text { and } \\
\text { placebo } \\
(\text { Vit } \mathrm{C}), 18 \\
\mathrm{~g}, \text { twice } \\
\text { daily group } \\
\text { (N=30). }\end{array}$ & 8 & $\begin{array}{l}\text { Variations of } \\
\text { HDS and BI }\end{array}$ \\
\hline
\end{tabular}

Early
fluoxetine
therapy plainly
hinders PSD
development.
As the level of
platelet 5-HT
rises, recovery
of neurologic
function
becomes
possible.

In the the group, $\mathrm{H} f$ DAL, a] neurolo functic differe significa from plac after eis weeks (1 5.3 vs. 1 3.7; 8.66 . 11.26 .4 ;

12.5 vs. ? 13.5, $\mathrm{P}$ $0.01)$. In therapy g] platelet 5 concentra were consider: lower af eight wee treatme [(325.3 1:

$\mathrm{mg} / \mathrm{L} \mathrm{v}$ (653.6 13 $\mathrm{mg} / \mathrm{L}, \mathrm{F}$ 0.05], whi notabl variatio were fou plasma 5 levels (1 0.05)

At the en this stur there wa statistici PSD. Based on significi
these findings, differenc
we can infer response : PSD. Based on significi
these findings, differenc
we can infer response : we can infer response appears to be FEWP gr well tolerated and th and may be a fluoxeti potential group (6 therapeutic against 6 ? alternative for 2 versus (

patients with $\quad \mathrm{p}=0.0$ ! PSD.
FEWF produci significa bette] improven in depres as oppost 


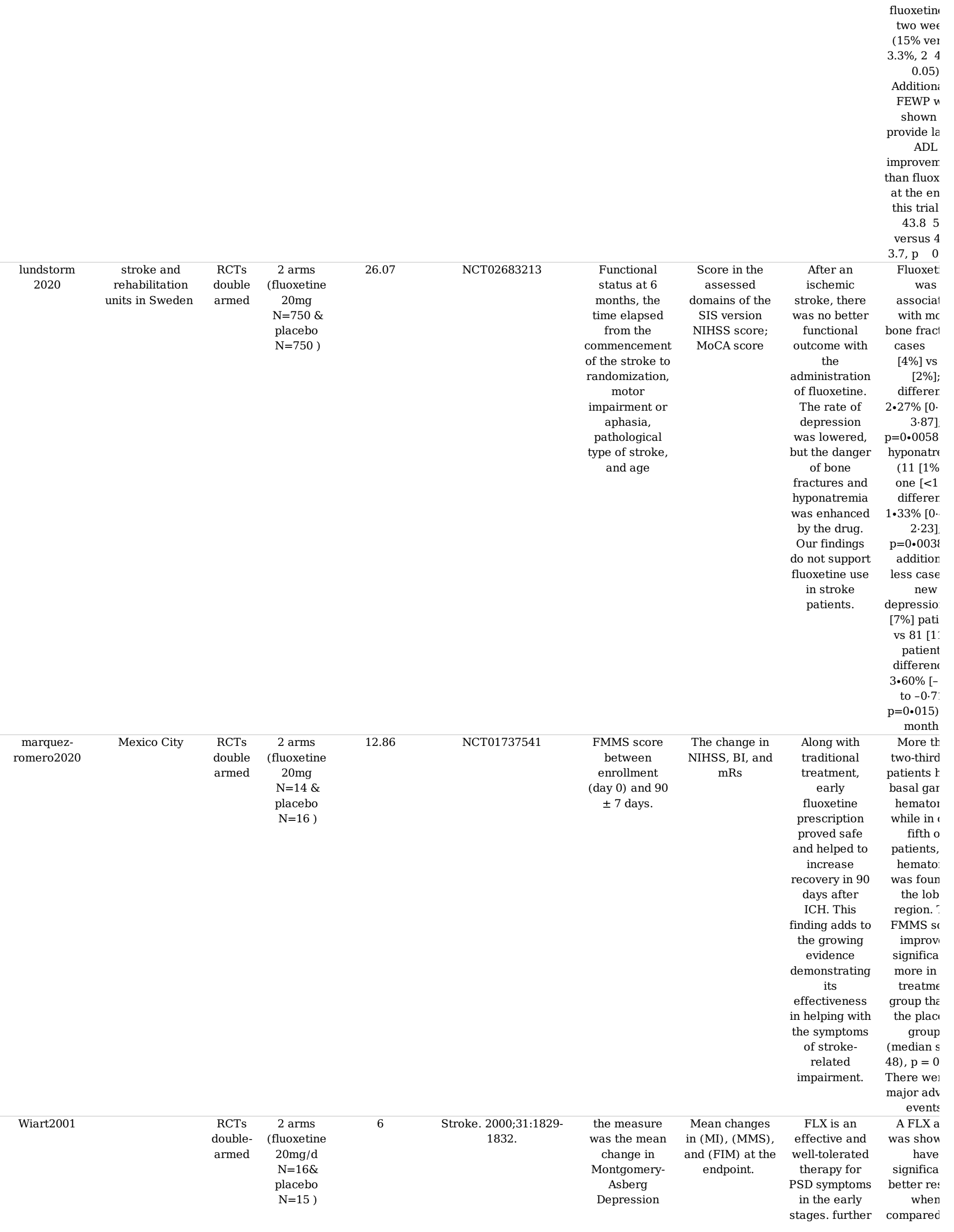

Page 14/20 
is required to fully

understand

the long-term

effects and

safety of this

medication. the endp

with c

differenc

MADRS sc

of (11.8

[mean \pm

versus $1 \varepsilon$

10.0,

respectiv

P50.05

Addition:

the FLX

displaye

highe:

response

(62.5\% ve

$33.3 \%$

respectiv

and a bic

mean dro

the MAL

(16.6 ver

8.4

respectiv

P50.02).

FLX

treatme

There are

no chang,

motor

cognitive

functiol

improven

with th.

exception

patient $\mathrm{v}$

consider:

and tempc

transamis

elevatic

Table 2: Baseline characteristics of the enrolled patients in included studies 


\begin{tabular}{|c|c|c|c|c|c|c|c|c|c|c|}
\hline \multirow[t]{2}{*}{ Study ID } & \multirow[t]{2}{*}{ Arms } & \multirow[t]{2}{*}{ total number } & \multirow{2}{*}{$\begin{array}{c}\text { Age } \\
M \pm S D\end{array}$} & \multicolumn{2}{|c|}{$\operatorname{sex}$} & \multicolumn{5}{|c|}{ Risk factors $\mathrm{N}$} \\
\hline & & & & $\begin{array}{c}\text { male } \\
\mathrm{n}(\%)\end{array}$ & $\begin{array}{c}\text { female } \\
\mathrm{n}(\%)\end{array}$ & HTN & Dyslipidemia & Smoking & $\mathrm{CAD}$ & diabetes \\
\hline \multirow[t]{2}{*}{ Asadollahi 2018} & Fluoxetine & 30 & $60.2(8.52)$ & $15(50)$ & $15(50)$ & 22 & 14 & 7 & 8 & \\
\hline & placebo & 30 & $61.7(9.6)$ & $18(60)$ & $12(40)$ & 23 & 10 & 9 & 5 & \\
\hline \multirow[t]{2}{*}{ Bembenek 2020} & Fluoxetine & 30 & $66.60(12.60)$ & $22(73.3)$ & $8(26.7)$ & 19 & 6 & 20 & 5 & 6 \\
\hline & placebo & 31 & 66.35 (12.46) & 18(58.06) & $13(41.9)$ & 17 & 5 & 22 & 6 & 9 \\
\hline \multirow[t]{2}{*}{ boninpinto2019 } & Fluoxetine & 10 & 50.5 (16.57) & $5(50)$ & $5(50)$ & & & & & \\
\hline & placebo & 8 & 57.38 (9.96) & $6(75)$ & $2(25)$ & & & & & \\
\hline \multirow[t]{2}{*}{ choi-kwon2005 } & Fluoxetine & 76 & $58.41(8.92)$ & $57(75)$ & $19(25)$ & $67(88.2)$ & $21(27.6)$ & 15 (19.7) & $4(5.3)$ & $22(28.9)$ \\
\hline & placebo & 76 & $58.18(8.85)$ & $60(78.9)$ & $16(21.05)$ & $54(71.1)$ & $16(21.1)$ & $11(14.5)$ & $3(3.9)$ & $22(28.9)$ \\
\hline \multirow[t]{2}{*}{ choi-kwon2006 } & Fluoxetine & 40 & $57.2(8.3)$ & $32(80.0)$ & $8(20)$ & $26(65.0)$ & $11(27.5)$ & $7(17.5)$ & $1(2.5)$ & $12(30.0)$ \\
\hline & placebo & 43 & $56.4(8.4)$ & $35(81.4)$ & $8(18.6)$ & $32(74.4)$ & $10(23.3)$ & $6(14.0)$ & $2(4.7)$ & $11(25.6)$ \\
\hline \multirow[t]{2}{*}{ chollet2011 } & Fluoxetine & 59 & 66.(11.7) & $37(63)$ & $22(37.29)$ & $39(66)$ & $36(61)$ & $30(51)$ & $34(58)$ & $14(24)$ \\
\hline & placebo & 59 & $62.9(13.4)$ & $35(59)$ & $24(40.68)$ & $40(68)$ & $33(56)$ & $26(44)$ & $28(47)$ & 11 (19) \\
\hline \multirow[t]{2}{*}{ dam 1998} & Fluoxetine & 16 & $67.5(8.9)$ & $7(43.75)$ & $9(56.25)$ & & & & & \\
\hline & placebo & 16 & $68.4(5.5)$ & $7(43.75)$ & $9(56.25)$ & & & & & \\
\hline \multirow[t]{2}{*}{ dennis2018 } & Fluoxetine & 1564 & $71.2(12.4)$ & $975(62)$ & $589(38)$ & & & & 281 & 337 \\
\hline & placebo & 1563 & $71.5(12.1)$ & $947(61)$ & $616(39)$ & & & & 300 & 303 \\
\hline \multirow[t]{2}{*}{ fruehwald2003 } & Fluoxetine & 26 & $64.8(13.8)$ & $12(46.15)$ & $14(53.85)$ & & & & & \\
\hline & placebo & 24 & $64.0(14.3)$ & $17(70.8)$ & $7(29.167)$ & & & & & \\
\hline \multirow[t]{2}{*}{ gong2020 } & Fluoxetine & 56 & $56.68(17.59)$ & $36(64.29)$ & $20(35.71)$ & 32 & 27 & 17 & & 17 \\
\hline & placebo & 54 & $57.79(17.54)$ & $33(61.11)$ & 21(38.89) & 30 & 26 & 15 & & 18 \\
\hline \multirow[t]{2}{*}{ hankey 2020} & Fluoxetine & 642 & $63.5(12.5)$ & $411(64)$ & $231(36)$ & & & & 58 & 143 \\
\hline & placebo & 638 & $64.6(12.2)$ & $393(62)$ & 245 (38) & & & & 57 & 147 \\
\hline \multirow[t]{2}{*}{ he 2016} & Fluoxetine & 179 & $60.46(10.35)$ & $129(72.1)$ & $50(27.9)$ & 133 & & 60 & & 55 \\
\hline & placebo & 171 & $62.66(11.69)$ & $120(70.2)$ & $51(29.8)$ & 130 & & 50 & & 64 \\
\hline \multirow[t]{2}{*}{ kong2007 } & Fluoxetine & 37 & $64(7)$ & $22(60)$ & $15(40)$ & & & & & \\
\hline & placebo & 36 & $62(7)$ & $20(55.556)$ & $16(44.4)$ & & & & & \\
\hline \multirow[t]{2}{*}{ li2008 } & Fluoxetine & 60 & $69.2(3.50)$ & $25(41.667)$ & $35(58.33)$ & & & & & \\
\hline & placebo & 30 & $67.8(3.9)$ & $17(56.667)$ & $13(43.33)$ & & & & & \\
\hline \multirow[t]{2}{*}{ lundstorm 2020} & Fluoxetine & 750 & $70.6(11.3)$ & $463(62)$ & $287(38)$ & & & & 123 & 140 \\
\hline & placebo & 750 & $71.0(10.50$ & $462(62)$ & $288(38)$ & & & & 111 & 159 \\
\hline \multirow[t]{2}{*}{ marquez-romero2020 } & Fluoxetine & 14 & $54(7.41)$ & $8(57.14)$ & $6(42.86)$ & 13 & 2 & 4 & & 2 \\
\hline & placebo & 16 & $60.5(13.33)$ & $7(43.75)$ & $9(56.25)$ & 15 & 1 & 4 & & 3 \\
\hline \multirow[t]{2}{*}{ Wiart2001 } & Fluoxetine & 16 & $66.3(7.1)$ & $9(56.25)$ & $7(43.75)$ & & & & & \\
\hline & placebo & 15 & $68.9(11.6)$ & $6(40)$ & $9(600$ & & & & & \\
\hline
\end{tabular}

\section{Figures}




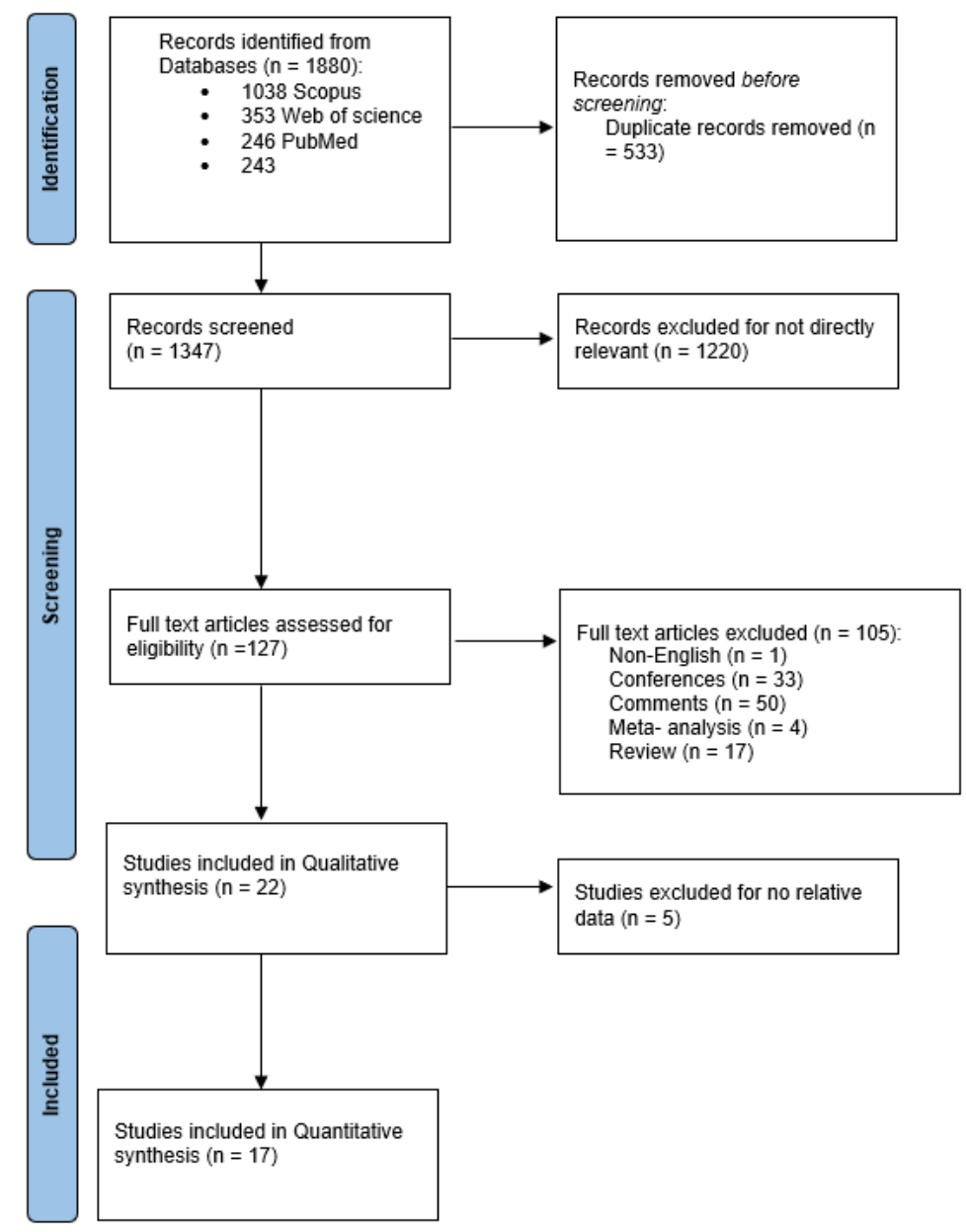

Figure 1

The study search, selection, and inclusion process 


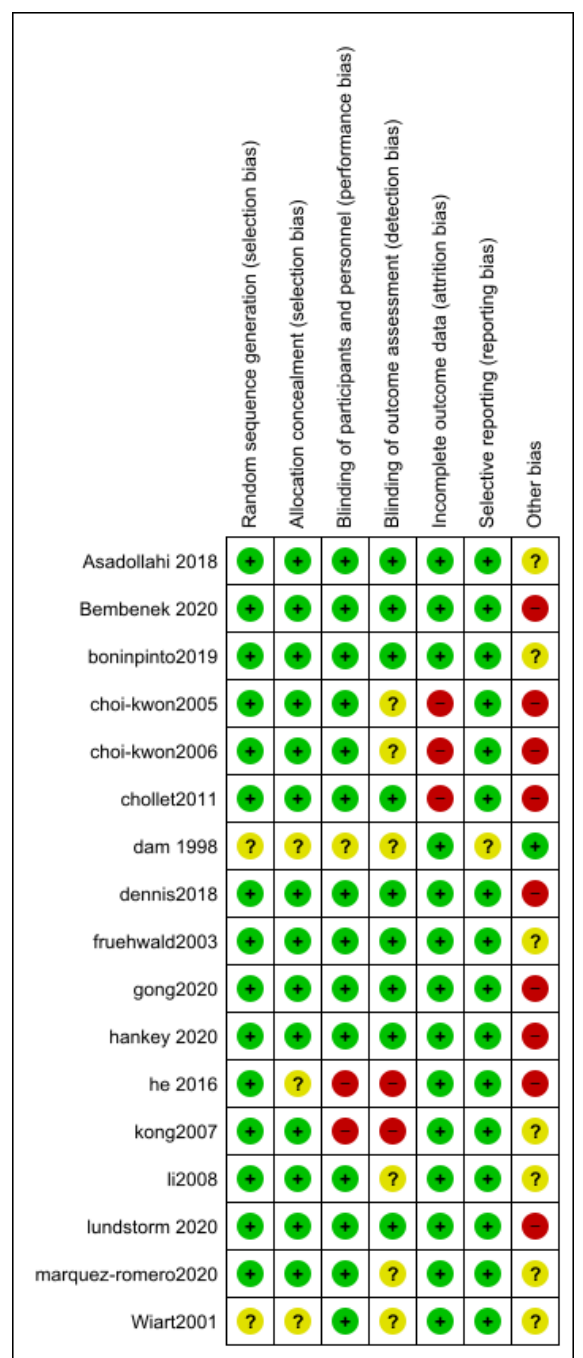

\section{Figure 2}

Risk of bias: a summary table for each risk of bias item for each study

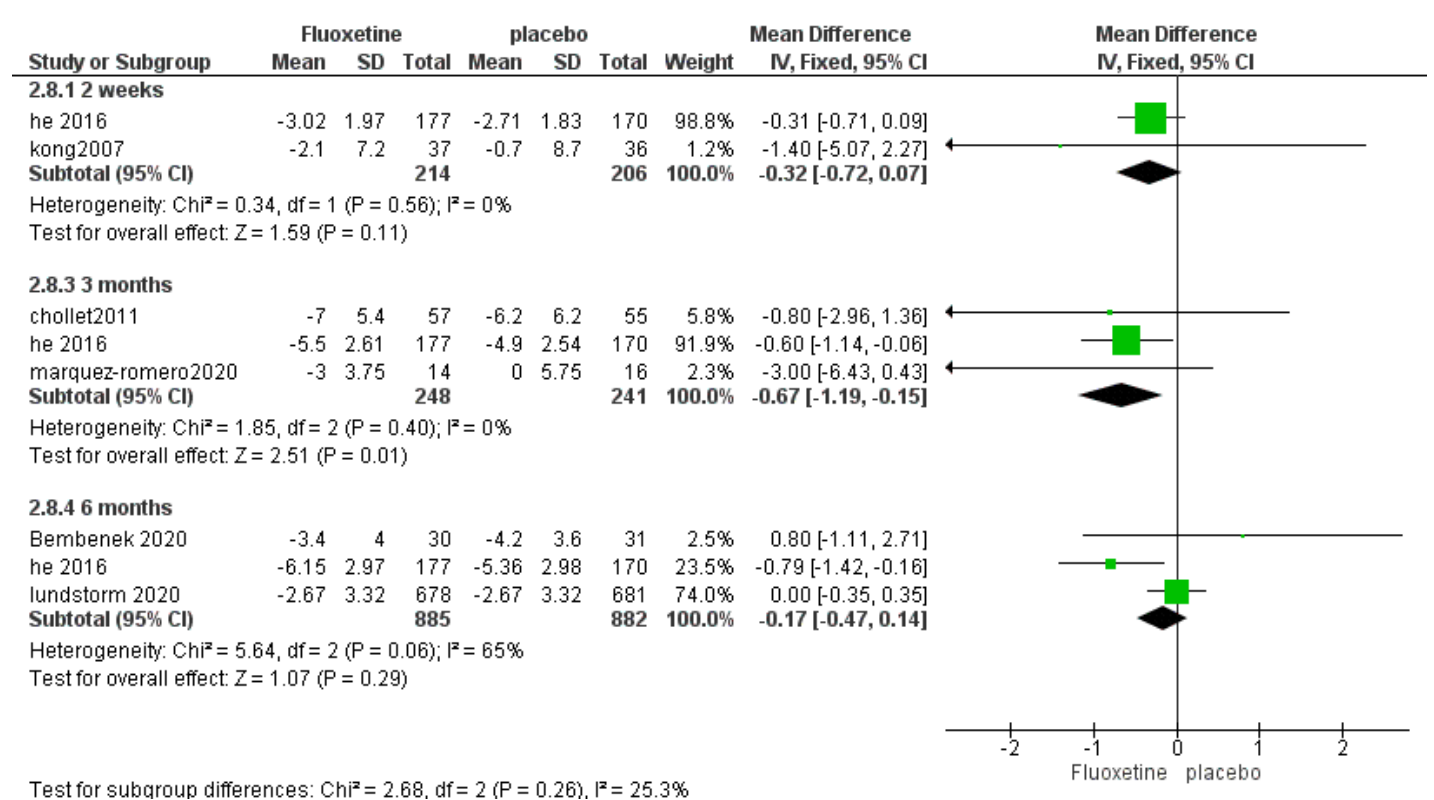

\section{Figure 3}

The pooled mean difference of the National Institutes of Health Stroke Scale (NIHSS) 


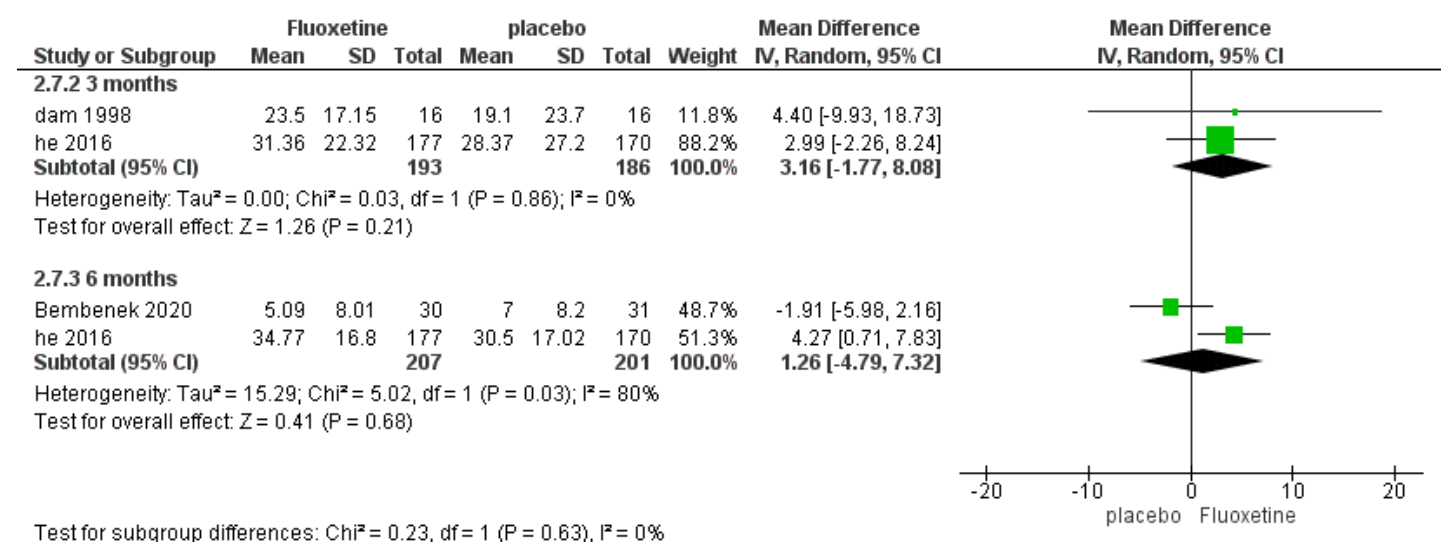

\section{Figure 4}

The pooled mean difference of the Barthel Index (BI)

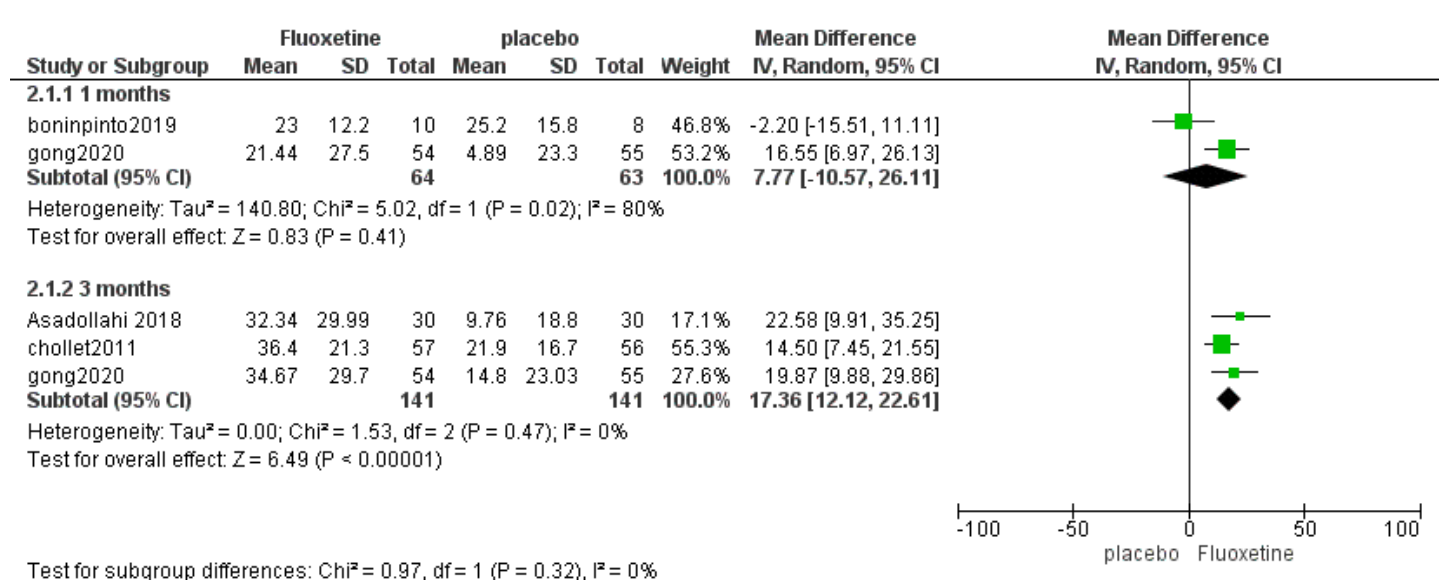

\section{Figure 5}

The pooled mean difference of the Fugl-Meyer Motor Scale (FMMS) 


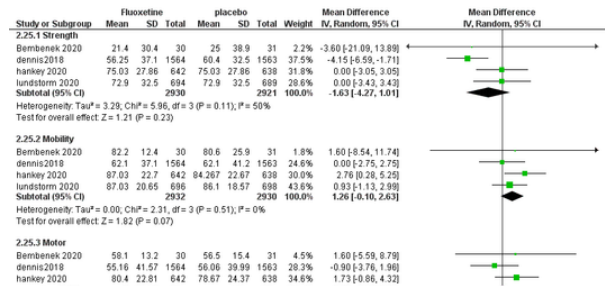

Figure 6

The pooled mean difference of the Stroke Impact Scale (SIS)

\section{Supplementary Files}

This is a list of supplementary files associated with this preprint. Click to download.

- OnlineResource1.docx 